\title{
Stimulated biodegradation of spent lubricating motor oil in soil amended with animal droppings
}

\author{
Stanley Chukwudozie Onuoha ${ }^{1,}$, Edna Ifeoma Chukwura ${ }^{2}$, Kayode Fatokun ${ }^{3}$ \\ ${ }^{1}$ Department of Biotechnology, Ebonyi State University, PMB 053 Abakaliki, Ebonyi State, Nigeria \\ ${ }^{2}$ Department of Applied Microbiology and Brewing, Nnamdi Azikiwe University, Awka, Anambra State, Nigeria \\ ${ }^{3}$ Department of Agriculture, University of Zululand, PMB X1001 KwaDlangezwa 3886, South Africa
}

\section{Email address:}

sconuoha@yahoo.com (S. C. Onuoha)

\section{To cite this article:}

Stanley Chukwudozie Onuoha, Edna Ifeoma Chukwura, Kayode Fatokun. Stimulated Biodegradation of Spent Lubricating Motor Oil in Soil Amended with Animal Droppings. American Journal of BioScience. Vol. 2, No. 1, 2014, pp. 19-27.

doi: 10.11648/j.ajbio.20140201.14

\begin{abstract}
The potentials of organic wastes from animal droppings as bioremediation alternative for soils spiked with waste-lubricating motor oil (spent oil) was evaluated. The rate of biodegradation of the spent oil was studied for a period of 6 months under laboratory condition. The result of the microbial counts for soils spiked with $5000 \mathrm{mgkg}^{-1}(0.5 \%)$ spent oil has its total heterotrophic bacterial count in unamended control soil ranging from $2.71 \pm 0.09$ to $7.21 \pm 0.25 \times 10^{6} \mathrm{CFU} / \mathrm{g}$ of soil, while those of soil amended with cow droppings (CD) ranged from $16.0 \pm 1.01$ to $47.90 \pm 0.36 \times 10^{6} \mathrm{CFU} / \mathrm{g}$ of soil and those of soil amended with goat droppings (GD) and poultry manure(PM) ranged from $16.6 \pm 0.6$ to $57.9 \pm 0.15 \times 10^{6}$ and $18.00 \pm 0.20 \times 10^{6}$ to $60.80 \pm 1.19 \times 10^{6} \mathrm{CFU} / \mathrm{g}$ of soil respectively. The counts of hydrocarbon-utilizing bacteria (HUB) in unamended control soil ranged from $0.93 \pm 0.11$ to $2.10 \pm 0.15 \times 10^{6} \mathrm{CFU} / \mathrm{g}$ of soil. The count of HUB in PM amended soil was significantly higher than those amended with goat droppings (GD), while those of goat dropping were higher than those of cow dung. The HUB count in GD amended soil ranged from $8.07 \pm 0.12 \times 10^{6}$ to $67.70 \pm 0.68 \times 10^{6} \mathrm{cfu} / \mathrm{g}$ of soil. The THB and HUB counts for soils spiked with $25000 \mathrm{mg} / \mathrm{kg}(2.5 \%)$ spent oil exhibited a similar trend as was observed for soil spiked with $0.5 \%$ spent oil. Evaluation by the first-order kinetic model which utilized combined data for the entire period revealed that PM with biodegradation rate constant of 0.2332 day- ${ }^{1}$ and half-life of 2.97 days was better in stimulating biodegradation of oil at higher concentration, while GD with a biodegradation constant of 0.3253 day- ${ }^{1}$ and half-life of 2.13 days performed better at low pollution when compared to that of PM and CD.
\end{abstract}

Keywords: Biodegradation, Waste-Lubricating Oil, Bacteria, Organic Waste, Hydrocarbon

\section{Introduction}

Contamination of soil by used lubricating oil is prevalent in oil producing and industrialized countries of the world. The problem is more severe in the developing countries where there is no effective regulatory polices on the environment (Onuoha et al., 2011).

The presence of different types of automobile and machinery has resulted in an increase in the use of lubricating oil. Also, oil spills from industries, filling stations, loading and pumping stations, petroleum product depots during transportation and at auto mechanic workshops, all combine to contribute to soil contamination (Onuoha et al., 2011).

Hydrocarbon contamination of the air, soil, fresh water especially by polycyclic aromatic hydrocarbon (PAHs) attracts public attention because many PAHs are toxic, mutagenic, and carcinogenic (Clemente et al., 2001). Prolong exposure of high oil concentration may cause the development of liver or kidney diseases, possible damage to the bone marrow and increased risk of cancer (Lloyd and Cackette, 2011). In addition, used motor oil contains metals and heavy polycyclic aromatic hydrocarbons (PAHS) that could contribute to chronic hazards including mutagenicity and carcinogenicity (Boonchan et al., 2000).

The problems of pollution have led to the exploration of many remedial approaches to effect the cleanup of the polluted soils. Pollution control strategies involving physico-chemical methods have often aggravated the problem rather than eliminate it. Biodegradation is favored as a good option for the remediation of polluted sites mainly because it uses inexpensive equipment, 
environmentally friendly and simple.

Bioremediation is one of the forms of biodegradation which involves the use of microorganisms to detoxify or remove organic and inorganic xenobiotic compounds from the environment. The process relied upon microbial enzymatic activities to transform or degrade the contaminants from the environment (Philip et al., 2005). The method has been investigated by several research studies to remediate petroleum polluted soil using various nutrient sources such as inorganic fertilizer, Urea, sawdust, compost manure and biosolids (Cho et al., 1997 and Namkoong et al., 2002). Mushroom compost and spent mushroom compost (SMC) has been applied in treating organo pollutant contaminated sites (Eggen, 1999; TrejoHernandez et al., 2006).

Addition of SMC results in enhanced PAH - degrading efficiency $(68 \%)$ as compared to the removal by sorption on immobilized SMC (46\%). It was observed that the addition of SMC to the concentrated medium reduced the toxicity, added enzymes, microorganisms and nutrients involved in the degradation of PAHS (Lau et al., 2003). Organic wastes like Banana skin, spent mushroom compost and brewery spent grain were found to enhance the biodegradation of used lubricating oil up to $90 \%$ loss of oil within the period of 3 months (Abioye et al., 2009b, 2010).

Ijah and Antai (2003) reported high degradation of hydrocarbon in soil contaminated with $10 \%$ and $20 \%$ crude oil compared to those contaminated with $30 \%$ and $40 \%$ crude oil with experienced partial degradation within a period of 12 months. In another study using poultry manure as organic fertilizer in contaminated soil, biodegradation was reported to be enhanced in the presence of poultry manure alone, but the extent of biodegradation was influenced by the incorporation of alternate carbon substrate or surfactant (Okolo et al., 2005).

The aim of this research is to explore the feasibility of using animal droppings that is widely available within our environment as a remediation alternative in oil polluted soil.

\section{Materials and Methods}

\subsection{Collections and Processing of Samples}

The soil sample used for bioremediation was collected randomly with a hand- dug soil auger at a depth of $15 \mathrm{~cm}$ from an agricultural farm in Afikpo. They were bulked to form a composite sample and transported in a sack to the laboratory, air dried and sieved through a $2 \mathrm{~mm}$ mesh.

Spent motor oil: - The spent motor oil used for the experiment was obtained fresh from a drained motor car engine.

Poultry manure, cow dung and goat dung: - The poultry manure (PM), cow dung CD) and goat dung (GD) were obtained from Farms located in Abakaliki, Ebonyi State, Nigeria. They were sun dried for 3 days and pulverized in order to accelerate distribution of nutrients to the microbes.

\subsection{Analysis of Soil and Organic Waste Characteristics}

Measures were made of some of the soils and organic wastes physicochemical parameters, such as particle size distribution, concentration of organic carbon, nitrogen, phosphorus, moisture and $\mathrm{pH}$ following standard methods from APHA (1998).

\subsection{Soil Preparation}

Two hundred grams $(200 \mathrm{~g})$ of sieved $(2 \mathrm{~mm})$ soil was contaminated with $2.5 \%$ and $0.5 \%(\mathrm{w} / \mathrm{w})$ of spent lubricating oil and thoroughly mixed. $10 \%(\mathrm{w} / \mathrm{w})$ of different animal droppings (PM, CD, GD) were also mixed separately with the oil contaminated soil. Plastic containers were filled with the soil-oil-organic waste (animal droppings) mixture. Control vessel consisting of soil-oil mixture without organic waste was also set up. The moisture content was adjusted by adding water one day prior to sampling and incubation was at room temperature $\left(28 \pm 2^{0} \mathrm{C}\right)$. The content of each vessel were tilled twice a week for aeration, and moisture content was maintained at $60 \%$ water holding capacity by addition of distilled water. The experiment was set up in triplicate. The design of the experiment is as shown in Table1

Table 1. Remediation Experimental Design.

\begin{tabular}{ll}
\hline Treatments & Details OF Treatments \\
\hline A & $200 \mathrm{~g} \mathrm{SOIL}+0.5 \% \mathrm{OIL}+10 \% \mathrm{PM}$ \\
$\mathrm{B}$ & $200 \mathrm{~g} \mathrm{SOIL}+0.5 \% \mathrm{OIL}+10 \% \mathrm{CD}$ \\
$\mathrm{C}$ & $200 \mathrm{~g} \mathrm{SOIL}+0.5 \% \mathrm{OIL}+10 \% \mathrm{GD}$ \\
D & $200 \mathrm{~g} \mathrm{SOIL}+0.5 \% \mathrm{OIL}$ \\
E & $200 \mathrm{~g} \mathrm{SOIL}+2.5 \% \mathrm{OIL}+10 \% \mathrm{PM}$ \\
F & $200 \mathrm{~g} \mathrm{SOIL}+2.5 \% \mathrm{OIL}+10 \% \mathrm{CD}$ \\
G & $200 \mathrm{~g} \mathrm{SOIL}+2.5 \% \mathrm{OIL}+10 \% \mathrm{GD}$ \\
H & $200 \mathrm{~g} \mathrm{SOIL}+2.5 \% \mathrm{OIL}$ \\
\hline
\end{tabular}

Key: Pm=Poultry Manure; $\mathrm{Cd}=$ Cow Dung; $\mathrm{Gd}=$ Goat Droppings

\subsection{Sampling}

Periodic sampling from each vessel was carried out on day 0 , that is, 7 days post pollution/contamination then at one month interval for 6 months. Composite samples were obtained by mixing $5 \mathrm{~g}$ of soil collected from different area of the microcosm by assaying for the total heterotrophic bacteria (THB), hydrocarbon-utilizing bacteria (HUB), $\mathrm{pH}$, total hydrocarbon content (THC), as well as isolation of bacteria.

\subsection{Enumeration and Identification of Bacteria in Soil}

Three replicate samples from each oil-polluted soil were withdrawn monthly for enumeration of total heterotrophic bacteria count. Serially diluted samples $(0.1 \mathrm{ml})$ of appropriate dilution (dilution that produce colony counts of between 30- 300 colonies) of soil suspension in sterile water (formed from $1.0 \mathrm{~g}$ of soil in $1 \mathrm{~L}$ of sterile water) on 
nutrient agar plates using the spread plate technique (Odokuma and Okpokwasili, 1993; Odokuma and Ibor, 2002). Bacteria colonies were enumerated after $48 \mathrm{~h}$ of incubation at $30^{\circ} \mathrm{C}$.

Hydrocarbon-utilizing bacteria (HUB) in the soil samples were enumerated using modified mineral salt medium of Mills et al, (1978) 1.8g k $\mathrm{gPO}_{2}, 4.0 \mathrm{~g} \mathrm{NH} \mathrm{NL}_{4}$, $0.2 \mathrm{~g} \mathrm{mgSO}_{4} .7 \mathrm{H}_{2} \mathrm{O}, 1.2 \mathrm{~g} \mathrm{KH}_{2} \mathrm{PO}_{4}, 0.01 \mathrm{~g} \mathrm{FeS0}{ }_{4} .7 \mathrm{H}_{2} \mathrm{O}, 0.1 \mathrm{~g}$ $\mathrm{NaCl}, 20 \mathrm{~g}$ agar, in $1000 \mathrm{ml}$ distilled water, $\mathrm{pH} 7.4$ ). The vapour phase transfer method (Amanchukwu et al., 1989) was used, a filter paper saturated with sterile spent oil was aseptically placed on the inside of the inverted Petri dishes and the culture plates were incubated at $\left(28 \pm 2^{\circ} \mathrm{C}\right)$ for 7 days (Odokuma and Okpokwasili, 1993; Odokuma and Ibor, 2002). Plates yielding 30- 300 colonies were enumerated. Colonies of different hydrocarbon-utilizing bacteria were randomly picked and pure isolates were obtained by repeated sub-culturing on nutrient agar (oxoid). The bacteria isolates were characterized using microscopic techniques and biochemical tests. The identities of the isolates were determined by comparing their characteristics with those of known taxa as described by Bergey's manual of determinative bacteriology (Buchanon and Gibson, 1976)

\subsection{Total Hydrocarbon Content (THC) Determination in Soil Amended with Organic Wastes}

The residual hydrocarbon content in the oil polluted soil during the study period was determined gravimetrically by toluene cold extraction method of Adesodun and Mbagwu (2008). Soil samples (10 g) were weighed into 50ml flask and $20 \mathrm{ml}$ of toluene was added to extract the hydrocarbon in the soil. After shaking for $30 \mathrm{~min}$, the mixture was allowed to stand for $10 \mathrm{~min}$ and it was to then filtered through whatman Nol filter paper. The liquid phase of the extract was measured at $420 \mathrm{~nm}$ absorbance using a spectrophotometer (Model 6100 PYE UNICAM Instrument England). The THC in soil was estimated with reference to standard curve derived from fresh spent oil diluted with toluene. The total hydrocarbon content data (THC) obtained was fitted to the first order Kinetics model of
Yeung et al, (1997)

$$
\mathrm{Y}=\mathrm{ae}^{\mathrm{k}}{ }^{\mathrm{t}}
$$

Where $\mathrm{y}=$ residual hydrocarbon content in soil $\left(\mathrm{gkg}^{-1}\right)$

$\mathrm{a}=$ initial hydrocarbon content in soil $\left(\mathrm{gkg}^{-1}\right)$

$\mathrm{k}=$ biodegradation rate constant $\left(\right.$ day $\left.^{-1}\right)$

$\mathrm{t}=$ time (day)

The model estimated the biodegradation rate and halflife of the hydrocarbons in soil relative to treatments applied. Half-life was calculated from the model of yeung et al, 1997 as half- life $=\frac{=\ln (2)}{\mathrm{K}}$

The model was based on the assumption that the degradation rate of hydrocarbon positively correlated with the hydrocarbon pool size in soil (Yeung et al, 1997).

\subsection{Determination of Efficiency of Individual Organic Waste Applied to the Soil}

Assessment of the efficiency of individual organic wastes applied to the oil polluted soil was evaluated by determining the "net percentage loss" due to the individual amendment. It was calculated as follows:

Net $\%$ Loss $=$ percentage Loss in THC of oil polluted soil amended with organic waste \% loss in THC of unamended polluted soil

\subsection{Statistical Analysis}

Statistical analysis of data was carried out using analysis of variance (ANOVA), Least Significant Difference (LSD), and Correlation Coefficient Methods. These were used to determine the relationship between the variables.

\section{Results}

\subsection{Physiochemical Properties of Soil and Organic Wastes}

The physiochemical properties of the soil and the organic wastes used for bioremediation studies are shown in Table 2.

Table 2. Results of Physiochemical properties of soil and organic wastes.

\begin{tabular}{lllll}
\hline Parameter & Soil & Cow dung & Goat droppings & Poultry manure \\
\hline $\mathrm{pH}$ & $6.04 \pm 0.16$ & $6.30 \pm 0.26$ & $6.88 \pm 0.35$ & $6.98 \pm 0.06$ \\
Nitrogen (\%) & $0.35 \pm 0.06$ & $0.87 \pm 0.06$ & $1.20 \pm 0.19$ & $3.46 \pm 0.45$ \\
Phosphorus (mgkg) & $21.5 \pm 0.64$ & $20.73 \pm 0.95$ & $22.0 \pm 1.11$ & $31.20 \pm 1.74$ \\
Organic carbon (\%) & $8.20 \pm 0.25$ & $20.4 \pm 0.67$ & $17.5 \pm 0.74$ & $30.9 \pm 1.21$ \\
Moisture (\%) & $7.07 \pm 0.12$ & $8.17 \pm 0.16$ & $6.64 \pm 0.06$ & $6.80 \pm 0.03$ \\
Sand (\%) & $38.1 \pm 2.05$ & & & \\
Silt (\%) & $27.7 \pm 1.55$ & & & \\
Clay (\%) & $30.4 \pm 0.95$ & & & \\
Texture & & & & \\
\hline
\end{tabular}

Data presented are means of triplicate determination \pm standard deviation.

The soil had a $\mathrm{pH}$ of $6.04 \pm 0.16$ and a low concentration of nitrogen, carbon and phosphorus of $0.35 \pm 0.06 \%, 8.20 \pm$

$0.25 \%$ and $21.50 \pm 0.64 \%$ respectively. The cow dung (CD), goat droppings (GD) and poultry manure (PM) had a 
$\mathrm{pH}$ of $6.30 \pm 0.26,6.88 \pm 0.35$ and $6.98 \pm 0.06$ respectively. The poultry manure had a higher percentage of nitrogen $3.46 \pm 0.45 \%$ when compared to the low percentages recorded in cow dung $0.87 \pm 0.06 \%$ and goat droppings $1.20 \pm 0.19 \%$ (Table 2); also, the phosphorus and carbon content of the organic wastes were recorded as shown in Table 2. The moisture content for both soil and organic waste deviated from the optimum range of $(10-20 \% \mathrm{w} / \mathrm{w})$ (Less and Senior, 1995), the soil was $7.07 \pm 0.12 \%$, CD $8.17 \pm 0.16 \%$ while GD and PM were $6.64 \pm 0.06 \%$ and $6.80 \pm 0.03 \%$ respectively.

\subsection{Microbial Population Counts}

The total heterotrophic bacteria in unamended control soil and soil amended with animal droppings are presented in (Fig. $1 \& 2$ ). The total aerobic heterotrophic bacteria in soil amended with cow dung ranged between $16 \pm 1.01 \mathrm{x}$ $10^{6}$ to $47.9 \pm 0.36 \times 10^{6} \mathrm{CFU} / \mathrm{g}$, while that of soil amended with goat dropping (GD) and poultry manure (PM) ranged from $16.6 \pm 0.60 \times 10^{6}$ to $57.9 \pm 1.10 \times 10^{-6}$ and $18.0 \pm 0.20$ x $10^{-6}$ to $60.8 \pm 1.19 \times 10^{-6} \mathrm{cfu} / \mathrm{g}$ (Fig. $1 \& 2$ ). The unamended control soil had the total aerobic bacterial count ranging between $2.71 \pm 0.09 \times 10^{-6}$ and $7.2 \pm 0.25 \times 10^{-6}$ $\mathrm{CFU} / \mathrm{g}$. All the additives had a greater initial microbial population and exhibited an increase in numbers up to the third month. However toward the end of the study, bacteria population dropped in all the treatments. Similar result was equally obtained when the soil polluted with $2.5 \%$ spent oil was assayed (Fig. 2). Bacteria counts was significantly higher in soil amended in different animal droppings when compared to those of the control soil at $0.05 \%$ probability level, indicating the role of nutrient in the enhancement of bacteria population.

The plating technique was equally used in enumerating the hydrocarbon-utilizing bacteria. The counts of hydrocarbon - utilizing bacteria (HUB) in unamended control soil at the initial time were $2.10 \pm 0.15 \times 10^{6} \mathrm{cfu} / \mathrm{g}$. This value dropped to $0.93 \pm 0.11 \mathrm{cfu} / \mathrm{g}$ on the $3^{\text {rd }}$ month and gradually rose to $1.10 \pm 0.10 \times 10^{6} \mathrm{cfug}^{-1}$ on the $6^{\text {th }}$ month (Fig. 3). The counts of HUB were higher in oil contaminated soil amended with different animal droppings. The HUB counts in soil amended with PM were significantly higher than those amended with goat droppings (GD), while of those GD was significantly higher $(\mathrm{P}<0.05)$ than those of CD. HUB counts in PM amended soil at the beginning of experiment (day 0 ) was $10.1 \pm 0.15 \times 10^{6} \mathrm{cfu} / \mathrm{g}$, it gradually rose to the maximum, $77.7 \pm 0.64$ on the $4^{\text {th }}$ month, the value dropped to $59.4 \pm$ 1.22 on the $6^{\text {th }}$ month. The microbial population in cow dung amended soil ranged from $8.16 \pm 0.15 \times 10^{6} \mathrm{cfu} / \mathrm{g}$ to $50.76 \pm 0.45 \times 10^{6} \mathrm{cfu} / \mathrm{g}$, while the count of HUB in soil amended with goat droppings ranged from $8.07 \pm 0.12 \mathrm{x}$ $10^{6} \mathrm{cfu} / \mathrm{g}$ to $67.76+0.68 \times 10^{6} \mathrm{cfu} / \mathrm{g}$. The counts of HUB in soil polluted with $2.5 \%$ spent oil exhibited a similar trend as observed in $0.5 \%$ concentration of spent oil (Fig.4). There was a significant increase in the number of hydrocarbon- utilizing bacteria at $0.05 \%$ probability level in soil amended with animal droppings. The result of the microbial population obtained demonstrated microbial population in the different organic waste in the order $\mathrm{PM}>\mathrm{GD}>\mathrm{CD}>$ Control

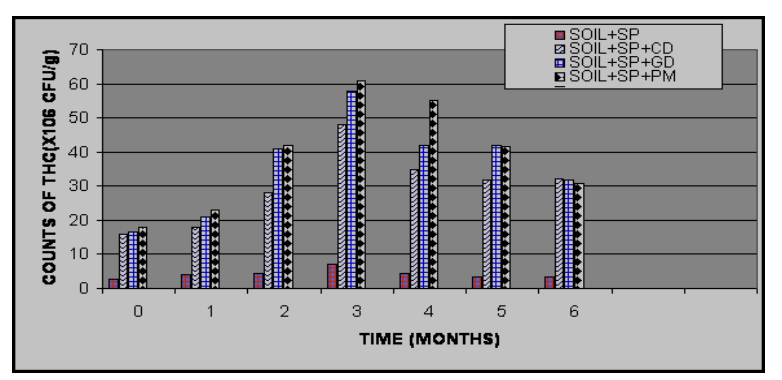

Fig 1. Counts of heterotrophic bacterial population in soil polluted with $0.5 \%$ spent oil

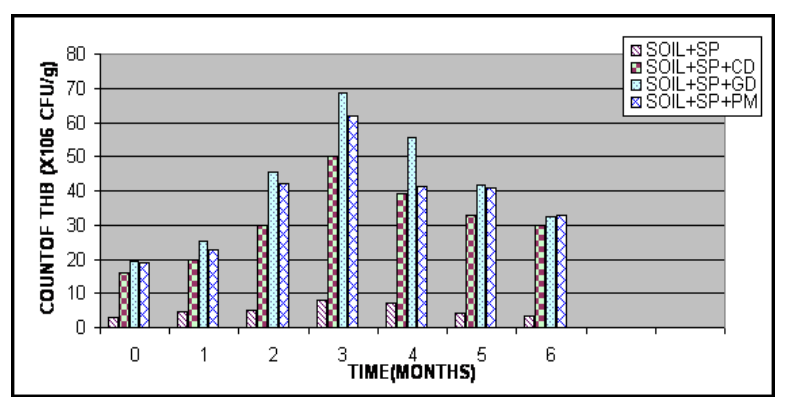

Fig 2. Counts of heterotrophic bacterial population in soil polluted with $2.5 \%$ spent oil

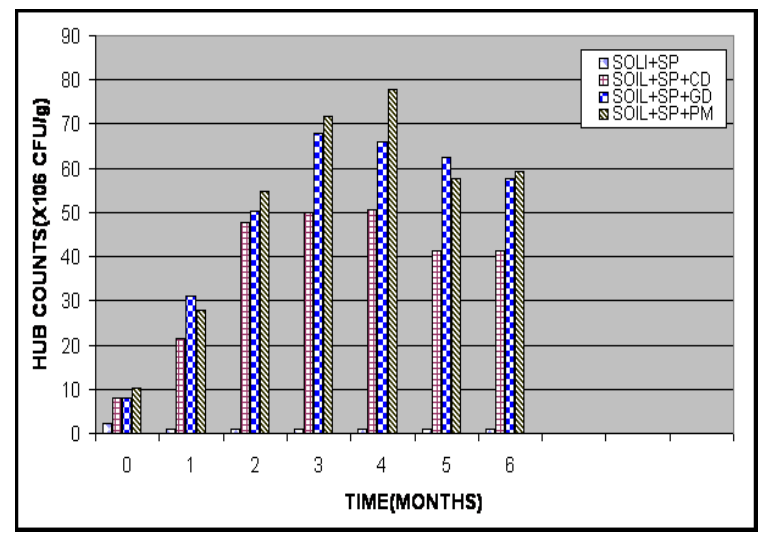

Fig 3. Counts of hydrocarbon -utilizing bacteria population in soil polluted with $0.5 \%$ spent oil

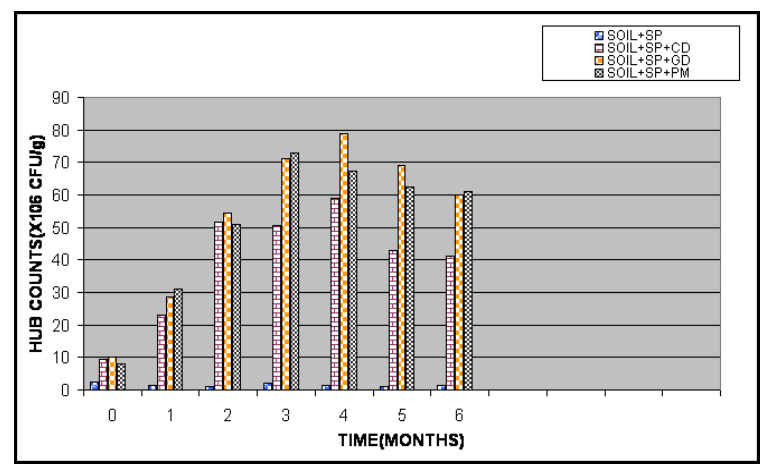

Fig 4. Counts of hydrocarbon -utilizing bacteria population in soil polluted with $2.5 \%$ spent oil 


\subsection{Biodegradation Pattern of Spent Oil in Soil Amended with Organic wastes}

The level of degradation of spent oil throughout the study period is shown in Fig. $5 \& 6$. There was a marked reduction in the total hydrocarbon content (THC) within the period of study with the addition of the animal droppings (organic wastes). At the end of the first month, soils polluted with $5000 \mathrm{mgkg}^{-1}(0.5 \%)$ spent motor oil showed a significant reduction in THC of $48 \%, 64.5 \%$ and $78.4 \%$ in soil amended with $\mathrm{CD}, \mathrm{PM}$, and GD respectively compared to $46.5 \%$ THC reduction in unamended control soil. In absolute terms, 2402, 3223 and $3921 \mathrm{mgkg}^{-1}$ of spent motor oil have disappeared from the CD, PM and GD amended soil, while $2326 \mathrm{mgkg}^{-1}$ disappeared from the unamended control soil (Fig. 5). But for soils polluted with $25,000 \mathrm{mg} / \mathrm{kg}(2.5 \%)$ spent oil, $5601 \mathrm{mg} / \mathrm{kg}(22.4 \%), 8119$ $\mathrm{mg} / \mathrm{kg}(32.5 \%), 16089 \mathrm{mg} / \mathrm{kg}(44.4 \%)$ and $8609 \mathrm{mg} / \mathrm{kg}$ (34.4\%) spent oil were lost from the control soil, CD, PM and GD amended soil (Fig.6).

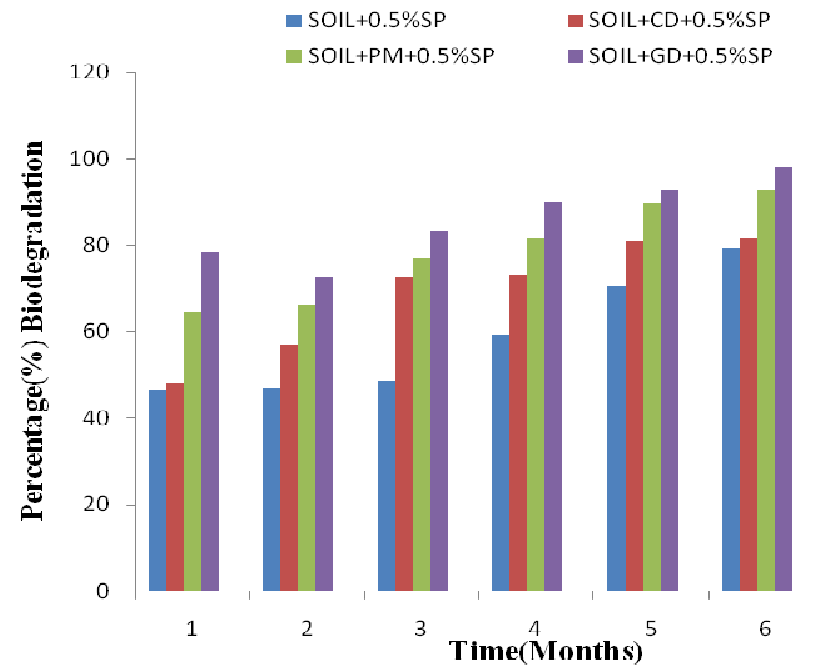

Fig 5. Percentage biodegradation of spent lubricating oil in a soil contaminated with $0.5 \%$ oil

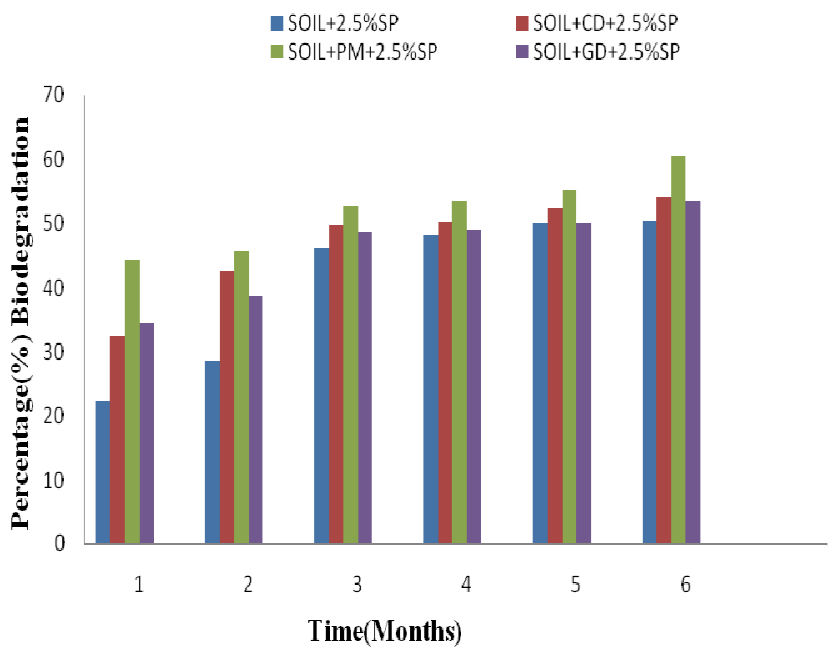

Fig 6. Percentage biodegradation of spent lubricating oil in a soil contaminated with $2.5 \%$ oil
At $2^{\text {nd }}$ months of treatments application, the level of reduction in THC from soil polluted with $0.5 \%$ spent motor oil was $46.7 \%$ (2334 $\left.\mathrm{mgkg}^{-1}\right)$ for unamended control soil, $56.8 \%\left(2841 \mathrm{mgkg}^{-1}\right)$ for CD amended soil, $66.2 \%(3310$ $\mathrm{mgkg}^{-1}$ ) for PM amended soil and 72.6\% (3631 $\left.\mathrm{mgkg}^{-1}\right)$ in PM amended soil (Fig. 5). For soils polluted with $2.5 \%$ spent oil, reduction in THC induced by nutrient supplementation was $7125 \mathrm{mg} / \mathrm{kg}(28.5 \%)$ for unamended control soil, $10655 \mathrm{mg} / \mathrm{kg}$ (42.6\%) for CD, $16250 \mathrm{mg} / \mathrm{kg}$ (65\%) for PM and $9655 \mathrm{mg} / \mathrm{kg}(38.6 \%)$ for GD amended soil (Fig.6).

After 6 months of application, the level of reduction of THC in soil polluted with $0.5 \%$ spent oil indicated a significant loss of $79.2 \%, 81.6 \%, 92.6 \%$ and $97.8 \%$ for unamended control soil, CD amended soil, PM amended soil and GD amended soil respectively. However, for soil polluted with $25,000 \mathrm{mg} / \mathrm{kg}$ of spent oil a significant loss of $50.4 \%, 54.1 \%, 60.5 \%$ and $54.4 \%$ of $\mathrm{THC}$ in unamended soil, CD, PM and GD amended soil were recorded respectively.

General observation at the end of the study demonstrated that all the animal droppings were effective in stimulating a significant lost or biodegradation of the spent oil with poultry manure more effective at both low $(0.5 \%)$ and high $(2.5 \%)$ oil pollution, whereas goat droppings was more effective in stimulating biodegradation of spent oil at low oil pollution.

Table 3. Net percentage Loss of total petroleum hydrocarbon on soil during bioremediation.

\begin{tabular}{lllllll}
\hline Treatments & $\mathbf{1}$ & $\mathbf{2}$ & $\mathbf{3}$ & $\mathbf{4}$ & $\mathbf{5}$ & $\mathbf{6}$ \\
\hline $\mathrm{CD}+0.5 \% \mathrm{SP}$ & $1.52^{\mathrm{f}}$ & $10.14^{\mathrm{e}}$ & $23.78^{\mathrm{c}}$ & $13.80^{\mathrm{d}}$ & $10.56^{\mathrm{d}}$ & $2.34^{\mathrm{f}}$ \\
$\mathrm{PM}+0.5 \% \mathrm{SP}$ & $17.94^{\mathrm{c}}$ & $19.52^{\mathrm{c}}$ & $28.22^{\mathrm{b}}$ & $22.38^{\mathrm{c}}$ & $19.16^{\mathrm{c}}$ & $13.40^{\mathrm{c}}$ \\
$\mathrm{GD}+0.5 \% \mathrm{SP}$ & $31.90^{\mathrm{a}}$ & $25.94^{\mathrm{b}}$ & $34.76^{\mathrm{a}}$ & $30.76^{\mathrm{a}}$ & $21.92^{\mathrm{b}}$ & $18.60^{\mathrm{b}}$ \\
$\mathrm{CD}+2.5 \% \mathrm{SP}$ & $10.07^{\mathrm{e}}$ & $14.12^{\mathrm{d}}$ & $3.67^{\mathrm{e}}$ & $1.76^{\mathrm{e}}$ & $2.32^{\mathrm{e}}$ & $3.70^{\mathrm{d}}$ \\
$\mathrm{PM}+2.5 \% \mathrm{SP}$ & $22.00^{\mathrm{b}}$ & $36.50^{\mathrm{a}}$ & $19.80^{\mathrm{d}}$ & $24.26^{\mathrm{b}}$ & $39.82^{\mathrm{a}}$ & $44.10^{\mathrm{a}}$ \\
$\mathrm{GD}+2.5 \% \mathrm{SP}$ & $12.03^{\mathrm{d}}$ & $10.12^{\mathrm{f}}$ & $2.74^{\mathrm{f}}$ & $0.74^{\mathrm{f}}$ & $0.01^{\mathrm{f}}$ & $3.00^{\mathrm{e}}$ \\
\hline
\end{tabular}

Key: Mean data in the same column carrying different superscript are significantly different at $\mathrm{P}<0.05$ level

$\mathrm{CD}=$ Cow dung; $\mathrm{GD}=$ Goat droppings; $\mathrm{PM}=$ Poultry manure; $\mathrm{SP}=$ Spent oil

\subsection{Biodegradation Rate Constant and Half-Life}

The biodegradation of used oil in the various treatments was further evaluated using first-order kinetics model of Yeung et al, (1997). Biodegradation constant (K) and halflife of the hydrocarbons during the bioremediation process was calculated from the model. The half-life indicates the time it takes for half of the hydrocarbon to degrade. Table 4 shows the biodegradation rate constant $(\mathrm{K})$ and half-life $\left(\mathrm{t}^{1} / 2\right)$ for the different treatments within the period of study. Data for the sampling periods were combined before this model could be used. From the values in the table, it could be obtained that soil amended with goat droppings showed the highest significant reduction in the THC for soil polluted 
with $0.5 \%$ spent oil with a biodegradation rate of 0.3253 day $^{-1}$ and half-life of 2.13 days. There was also significant reduction with addition of $\mathrm{PM}$ with a biodegradation rate of 0.2569 day- $^{1}$ and a half-life of 2.70 days. CD has a biodegradation rate of 0.1979 ; half-life of 3.50 days. The control soil had the least biodegradation rate of 0.1605 day${ }^{1}$ and half-life of 4.35 days.

Also the addition of PM, with a biodegradation rate of 0.2332 and half-life of 2.97 days, seems to be most effective in stimulating biodegradation of the spent oil in soil polluted with $2.5 \%$ spent oil. However, CD and GD with a half life of approximately 7 days showed a little effect at this level of pollution. General observation further confirms that GD was more effective in stimulating a significant reduction of spent oil at low concentration, while PM was more effective at both high and low oil levels.

Table 4. Biodegradation rate and half-life of hydrocarbon in oil polluted soil.

\begin{tabular}{lll}
\hline Treatments & $\begin{array}{l}\text { Biodegradation constant } \\
(\mathbf{K}) \text { day }^{-1}\end{array}$ & Half-life (t $1 / 2)$ day \\
\hline Soil+0.5\%SP & $0.1605^{\mathrm{e}}$ & $4.33^{\mathrm{d}}$ \\
Soil+CD+0.5\%SP & $0.197^{\mathrm{d}}$ & $3.50^{\mathrm{e}}$ \\
Soil+PM+0.5\%SP & $0.2569^{\mathrm{b}}$ & $2.70^{\mathrm{g}}$ \\
Soil+GD+0.5\%SP & $0.3253^{\mathrm{a}}$ & $2.13^{\mathrm{h}}$ \\
Soil+2.5\%SP & $0.0877^{\mathrm{h}}$ & $7.88^{\mathrm{a}}$ \\
Soil+CD+2.5\%SP & $0.1055^{\mathrm{f}}$ & $6.60^{\mathrm{c}}$ \\
Soil+PM+2.5\%SP & $0.2332^{\mathrm{c}}$ & $2.97^{\mathrm{f}}$ \\
Soil+GD+2.5\%SP & $0.1017^{\mathrm{g}}$ & $6.79^{\mathrm{b}}$ \\
\hline
\end{tabular}

Key: Mean data in the same row carrying different superscript are significantly different at $\mathrm{P}<0.05$ level

$\mathrm{CD}=$ Cow dung; $\mathrm{GD}=$ Goat droppings; $\mathrm{PM}=$ Poultry manure; $\mathrm{SP}=$ Spent oil.

\section{Discussion}

The result of total heterotrophic bacteria counts showed that there was a general increase in the THB in the entire vessel for both $0.5 \%$ and $2.5 \%$ (Figs. $1 \& 2$ ). However, control vessel increased at the lowest rate. Odokuma and Dickson, 2003 observed a similar behavior and noted that the relatively low values obtained in the control cell may have resulted from the toxicity of the crude- oil to the soil microbes, brought about by the high concentration of the crude-oil before the remediation treatments. For the other vessels increase in THB was significant within the first three months, however toward the end of the study, bacteria population dropped in all the treatments. The drop in number can be attributed to decline in the availability of readily metabolizable components of hydrocarbon for the organisms.

The counts of HUB in all the soil contaminated with $2.5 \%$ and $0.5 \%$ used lubricating oil are shown in (Fig. $3 \&$ 4). It was observed that HUB count in soil amended with different animal wastes were significantly higher $(\mathrm{P}<0.05)$ when compared with those of the control soil. These counts are comparable to those of Ijah and Antai (2003b), who observed counts of hydrocarbon degraders in oil polluted soil to be $\times 10^{6} \mathrm{cfu} / \mathrm{g}$ but lower than those of obtained by Antai and Mgbomo (1989) whose counts of HUB in hydrocarbon-contaminated soil was $\times 10^{8} \mathrm{cfu} / \mathrm{g}$. The reasons for higher counts of bacteria in amended soil may be the result of the presence of appreciable quantities of nitrogen and phosphorus in the animal wastes that enhanced the multiplication of bacteria in the soil. (Ijah and Antai 2003a; Joo et al, 2001, 2007; Adesodun and Mbagwu, 2008)

Also, it was observed that the population of HUB achieved highest count during the middle period of the study and witnessed a drop toward the end of the study. This can be attributed to decline in the availability of readily metabolizable components of hydrocarbon for the organisms. Dramatic changes in microbial populations have been reported by other author experimenting with nutrient supplemented, hydrocarbon contaminated soil (Ting et al, 1999, Vasudevan and Rajaram, 2001).

The result of the investigation has shown that hydrocarbon-utilizing bacteria were isolated and identified to be species of Pseudomonas, Corynebacterium, Bacillus, Acinetobacter and Micrococcus. These bacteria species has been implicated in hydrocarbon degradation by different authors (Ijah, 1998; Van Hamme et al., 2003; Bento et al, 2005; Onuoha et al., 2011).

The population of hydrocarbon- degraders from the treatment vessels showed that majority of the bacteria were Gram- positives belonging to the Actinobacteria group. Although some studies have shown that, oil polluted soils are dominated by Gram-negative bacteria (Macnaughton et al, 1999; Kaplan and Kitts, 2004), the dominant culturable hydrocarbon- utilizing bacteria from the soil investigated were made up of Gram- positive Actinobacteria of the genera Pseudomonas, Bacillus, Acinetobacter, Micrococcus and Corynebacterium, this corroborates the findings of Quatrini et al, (2008) who isolated 2 Rhodococcus, 2 Gordonia and 1 Norcadia strains as dominant hydrocarbondegraders from a hydrocarbon contaminated Mediterranean shoreline.

The results obtained in this study showed different degree of hydrocarbon utilization by the bacterial isolates when inoculated unto mineral salt medium containing spent oil as the sole source of carbon and energy. The result showed that Pseudomonas sp has the highest ability to degrade spent oil $66 \%$ followed by Corynebacterium, 59\%, Micrococcus, 49\% Acinetobacter, 43\% and Bacillus, 41\% (results not shown). The differences in the rate of hydrocarbon degradation may be due to presence of efficient catabolic genes involved in hydrocarbon degradation in the bacterial species (Kyung-Hwa et al, 2006; Majid et al, 2008).

Biodegradation studies revealed that the rates of oil breakdown in the soil increased with time. The different organic waste amended to the oil polluted soil, PM, CD and 
GD significantly $(\mathrm{P}<0.05)$ enhanced the degradation of the polluted soil when compared to the control soil with no amendments. The enhancement could be attributed to the nutrient in the organic waste which might have been released easily into the soil for use by oil degraders. It is also possible that hydrocarbon - utilizers inherent in the waste contributed to the biodegradation process. This finding is consistent with the work done by Williams et al, (1999) who used poultry litter to enhance the degradation of petroleum hydrocarbon in the soil.

General observation at the end of the study shows that heavy or high concentration of oil pollution has a reduced effect on the rate of microbial reduction of THC. The ineffectiveness of the organic wastes with heavy application of spent oil could be attributed to reduction in the activity of the soil microbes at that level of oil pollution. Bossert and Bartha (1984) stated that sensitivity of soil microflora to petroleum hydrocarbon is factor of quantity and quality of oil spilled and previous exposure of the native soil microbe to oil. Schaefer and Juliane, (2007) contended that bioremediation is useful method of soil bioremediation if pollutant concentrations are moderate.

The kinetic parameters observed in this study showed that the rate of degradation of spent oil in soil amended with PM and GD was high for the different concentrations of oil pollution. Addition of PM with a biodegradation rate constant of 0.2332 and half- life of 2.97 days was the most effective in stimulating biodegradation of oil at a high concentration, while GD with a higher biodegradation constant of 0.3253 , half-life of 2.13 has the highest rate of THC reduction in soil polluted with low oil concentration when compared with that of CD and PM. Since oil degradation is an natural process limited by temperature, $\mathrm{pH}$, and scarcity of nutrients such as $\mathrm{N}$ and $\mathrm{P}$ (Ladousse and Tramier, 1991; Leahy and Colwell, 1990), the higher rate of THC reduction reported in this study with the addition of PM and GD could be due to bioavailability of the nutrients in these organic wastes to bacterial species in the oil polluted soil.

Also, it is important to note that the observed reduction in spent oil or THC may not only be due to the biodegradation process induced by nutrient additions, but other processes such as volatilization, adsorption to organic compounds, other abiotic factors are equally implicated in the reduction process. This is the case in the two unamended control soil where there were up to $80 \%$ and $50 \%$ reduction in $\mathrm{THC}$ without any organic waste amendment.

It was observed that there was a gradual change in $\mathrm{pH}$ with time from the acidic to slightly alkaline range possibly in response to the application of the organic waste (Figure not shown)). There are studies which showed that degradation of oil increased with increasing $\mathrm{pH}$, with optimum degradation occurring under slighting alkaline conditions. (Dibble and Bartha, 1979; Foght and Westlake, 1987). The $\mathrm{pH}$ values obtained from this study corroborate the work of Foght and Westlake, (1987); Ijah and Ndana,
(2003) who observed similar findings in their work.

\section{Conclusion}

This investigation was aimed at determining the potential of animal droppings in enhancing biodegradation of spent lubricating motor oil as an alternative to the use of inorganic fertilizers which are very expansive. Results revealed that biodegradation of petroleum hydrocarbon were significantly enhanced by the addition of the animal droppings.

The THC reduction rate and the kinetic parameters determined for each treatment showed that PM and GD amended soil showed the highest rate of degradation when compared to those of $\mathrm{CD}$ and control. The result of the study also revealed that the unamended control soil performed extremely well paralleling the amended soil in THC reduction. This showed that remediation of an oil polluted environment can be achieved through natural processes of biodegradation, photo-oxidation, evaporation and volatilization without external interferences.

The large increase in microbial population in the amended soils suggests that the supplementation with the animal wastes may enhance degradation of petroleum hydrocarbon in nutrient - poor soils. The microorganisms identified in this study when produced in large numbers as biomass, can be applied as a consortium (bioaugmentation) in bioremediation of hydrocarbon- polluted environment.

\section{Acknowledgements}

The authors wish to acknowledge Prof. (Dame) E.I. Chukwura for her support during the course of the research. We shall ever remain grateful to her. Funding for this study was from personal contributions from the authors, no external funding.

\section{References}

[1] Abioye, O.P., Abdul Aziz, A and Agamuthu, P.(2009b). Stimulated biodegradation of used lubricating oil in soil using organic wastes. Malaysian Journal of Science. 28 (2):127-133.

[2] Abioye, O.P., Abdul Aziz, A and Agamuthu, P (2010). Enhanced biodegradation of used engine Oil in soil amended with organic wastes. Water Air and Soil pollution.209: 173- 179 .

[3] Adesodun, J.K. and Mbagwu, J.S.C (2008). Biodegradation of waste lubricating petroleum oil in a tropical alfisol as mediated by animal droppings. Bioresource Technology, 99: $5659-5665$.

[4] American Health Public Health Public Association (APHA) (1998). Standard Method for the examination of water and waste water, Washigton, DC

[5] Antai, S.P and Mgbomo (1989). Distribution of hydrocarbon utilizing bacteria in oil-spill areas. Microbiology Letters, 40:137-143 
[6] Bento, F.M., Carmago, F.O.A., Okeke, B.C., Frankenberger, W.T (2005). Comparative bioremediation of soil contaminated with diesel oil by natural attenuation, biostimulation and bioaugmentation. Bioresource Technology, 96:1049-1055.

[7] Bossert, I and Bartha, R. (1984). The fate of petroleum in soil ecosystems. In: Atlas, R.M. (Ed.), Petroleum Microbiology, Macmillan, New York, pp. 435-473.

[8] Buchanan R. V and Gibbons N. E. (1994). Bergey's Manual of Determinative Bacteriology, Williams and Wilkins Co., Baltimore, USA.

[9] Cho, B.H., Chino, H., Tsuji, H., Kunito, T., Nagaoka, K., Otsuka, S., Yamashita, K., Matsumoto, S and Oyaiz, H (1997). Laboratory -scale bioremediation of a contaminated soil of Kuwait with amendment materials. Chemosphere, 35 (7), 1599-1611.

[10] Clemente, A.R., anazawa, T.A and Durrant, L.R (2001). Biodegradation of polycyclic aromatic hydrocarbons by soil fungi. Brazilian Journal of Microbiology, 32:255-261.

[11] Dibble, T.T and Bartha, R (1979). Effect of environmental parameters on the biodegradation of oil sludge. Applied Environmental Microbiology, 37:729-739.

[12] Eggen, T. (1999). Application of fungal substrate from commercial mushroom production Pleurotus ostreatus for bioremediation of creosote contaminated soil. International Biodeterioration and Biodegradation, 44:117-126.

[13] Foght, J.M. and Westlake, D.W.S. (1987) Biodegradation of hydrocarbons in freshwater. In: Vandermeulen and Hrudey (Ed), Oil in Freshwater: Chemistry, Biology, Countermeasure Technology. Pergamon Press, New York, pp217-230.

[14] Ijah, U.J.J (1998). Studies on relative capabilities of bacterial and Yeasts isolates from tropical soils in degrading crude oil. Waste Management, 18: 293-299.

[15] Ijah, U.J.J and Antai, S.P (2003a). The potential use of chicken-drop microorganisms for oil spill remediation. The Environmentalist, 23:89-95

[16] Ijah, U.J.J and Antai, S.P. (2003b) Removal of Nigerian light crude oil in soil over a $12-$ month period. International Biodeterioration Biodegradation, 51: 93-99.

[17] Ijah, U.J.J and Ndana, M (2000). Stimulated biodegradation of crude oil in soil amended with periwinkle shells. The Environmentalist, 23: 249-254.

[18] Joo, H.S., Shoda, M and Phae. C.G (2007). Degradation of diesel oil in soil using a food waste composting process. Biodegradation, 18:597-605

[19] Joo, H.S., Phae. C.G and Ryu, J.Y (2001). Comparison and analysis of characteristics for recycling of multifarious food waste. J KOWREC, 9: 117-124.

[20] Kaplan, C.W and Kitt, C.L (2004). Bacterial succession in a petroleum land treatment unit. Applied Environmental Microbiology, 70:1777-1786.

[21] Kyung-Hwa, B.Y., Byung-Dae O., Hee-Mock., Hee-Sik, K and Sook, L (2006). Biodegradation of aliphatic and aromatic hydrocarbon by Norcadia sp. H17-1. Geomicrobiology Journal, 23 (5): 253 - 259.
[22] Ladousse, A. and Tramier, B. (1991) Results of 12 years of research in spilled oil bioremediation: Inipol EAP 22, Proceedings of 1991 Oil Spill Conference. American Petroleum Institute, Washington, DC, pp577-581.

[23] Lau, K.L., Tsang, Y.Y., Chiu, S.W. (2003). Use of spent mushroom compost to bioremediate PAH-contaminated samples. Chemosphere, 52 (9):1539-1546.

[24] Leahy, J.G., Colwell, R.R. (1990) Microbial degradation of hydrocarbons in the environment. Microbiological Review, 54: 305-315.

[25] Lloyd, C.A and Cackette, T.A (2001). Diesel engines: Environmental impact \& control. Air and waste management Association, 51: 805-847.

[26] Macnaughton, S.J., Stephen, J.R., Venosa, A.O., Davis, G.A., Chang, Y.J and White, D.C. (1999) Microbial population changes during bioremediation of an experimental oil spill. Applied Environmental Microbiology, 65: 3566-3574.

[27] Majid, Z.; V. Mnouchehr and K.A. Sussan (2008). Naphthalene metabolism in Norcardia Otitidis caviarum stream. TSHI, a moderately thermophilic microorganism. Chemosphere, 72: 905-909

[28] Mills, A.L., Brueil, C and Colwell, R.R (1978). Enumeration of petroleum degrading marine microorganisms by the most probable number method. Canadian Journal of Microbiology, 22: 552-557.

[29] Namkoong, W., Hwang, E., Park, J and Choi, J. (2002). Bioremediation of diesel- contaminated soil with composting. Environmental Pollution, 119: 23-31.

[30] Odokuma, L. O. and Ibor, M. N. (2002) Nitrogen fixing bacteria enhanced bioremediation of crude oil polluted soil. Global Journal of Pure and Applied Sciences. 8 (4): 455468.

[31] Odokuma, L.O and Dickson, A.A. (2003) Bioremediation of a crude oil - polluted tropical rain forest soil. Global Journal of Environmental Sciences, 2: 29-40

[32] Odokuma, L.O and Okpokwasili, G.C(1993). Seasonal ecology of hydrocarbon-utilizing microbes in the surface water of a river Environ.Mon. Assess 27(3) 175-191.

[33] Okolo, J.C., Amadi, E.N and Odu, C.T.I (2005). Effects of soil treatments containing poutry manure on crude oil degradation in a sandy loam soil. Applied Ecology and environmental Research, 3 (1): 47-53.

[34] Onuoha, S.C., Olugbue, V.U., Uraku, J.A and Uchendu, D.O (2011). Biodegradation potentials of hydrocarbon degraders from waste -lubricting oil spilled soils in Ebonyi State, Nigeria. International Journal of Agriculture and Biology, 13:586-590.

[35] Philips, J.C., Atlas, R.M. (2005). Bioremediation of contaminated soil and aquifers. In: Bioremediation: Applied Microbial solution for real-world environmental clean Up, Atlas, R.M., and Jim, C.P(ed) ASM press, ISBN 1-55591239-2, Washington, D.C, pp.139

[36] Quatrini, P., Scaglione, G., De Pasquale, C., Reila, S and Puglia, A.M. (2008) Isolation of Gram-positive n-alkane degraders from a hydrocarbon contaminated Mediterranean shoreline. Journal of Applied Microbiology, 104: 251- 259. 
[37] Schaefer, $M$ and Juliane, F (2007). The influence of earthworm and organic additives on the biodegradation of oil contaminated soil. Applied Ecology, 36: 53-62.

[38] Ting, Y.P., Hu, H.L and Tan, H.M (1999). Bioremediation of petroleum hydrocarbon in soil microcosm. Resource and Environmental Biotechnology, 2: 197-218.

[39] Trejo-Hernandez, M..R., Lopez-Munguia, A.R and Ramirez, Q. (2001). Residual compost of Agaricus biosporus as a source of crude Laccase for enzymatic oxidation of phenolic compounds. Process Biochemistry, 36: 635-639.

[40] Van Hamme, J.D., Singh, A and Ward, O.P. (2003). Recent advances in petroleum Microbiology. Molecular Biology Review, 67: 503-549.
[41] Vasudevan,N and Rajaram, P (2001). Bioremediation of oil sludge contaminated soil. Environment International. 26: 409-411.

[42] Williams, C.M., Grimes, J.L and Mikelssen, R.L (1999). The use of poultry litter as co-substrate and source of inorganic nutrient and microorganisms for the ex-situ biodegradation of petroleum compounds. Poultry litter, 78, 956-964.

[43] Yeung, P.Y., Johnson, R.L and Xu, J.G. (1997) Biodegradation of petroleum hydrocarbons in soil as affected by heating and forced aeration. Journal Environmental Quality, 26: 1511-1516. 